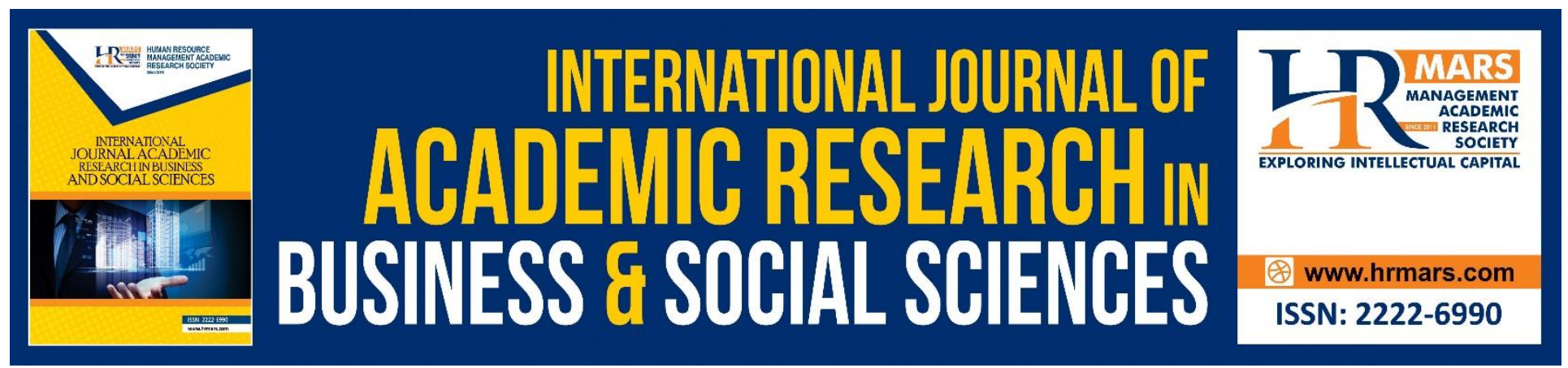

\title{
Intention to Eat Traditional Food among University Students
}

Norazlina Rahmat, Mohammad Nuruddin Ramlan, Puteri Nur Athirah Ghazali, Norzaidah Ngali

To Link this Article: http://dx.doi.org/10.6007/IJARBSS/v11-i13/8510

DOI:10.6007/IJARBSS/v11-i13/8510

Received: 12 November 2020, Revised: 15 December 2020, Accepted: 31 December 2020

Published Online: 22 January 2021

In-Text Citation: (Rahmat et al., 2021)

To Cite this Article: Rahmat, N., Ramlan, M. N., Ghazali, P. N. A., \& Ngali, N. (2021). Intention to Eat Traditional Food among University Students. International Journal of Academic Research in Business and Social Sciences, 11(13), 127-138.

Copyright: (c) 2021 The Author(s)

Published by Human Resource Management Academic Research Society (www.hrmars.com)

This article is published under the Creative Commons Attribution (CC BY 4.0) license. Anyone may reproduce, distribute, translate and create derivative works of this article (for both commercial and non-commercial purposes), subject to full attribution to the original publication and authors. The full terms of this license may be seen

at: $\underline{\text { http://creativecommons.org/licences/by/4.0/legalcode }}$

Special Issue: Beyond 2021 and COVID-19 - New Perspective in the Hospitality \& Tourism Industry, 2021, Pg. 127 - 138 http://hrmars.com/index.php/pages/detail/IJARBSS JOURNAL HOMEPAGE

Full Terms \& Conditions of access and use can be found at http://hrmars.com/index.php/pages/detail/publication-ethics 


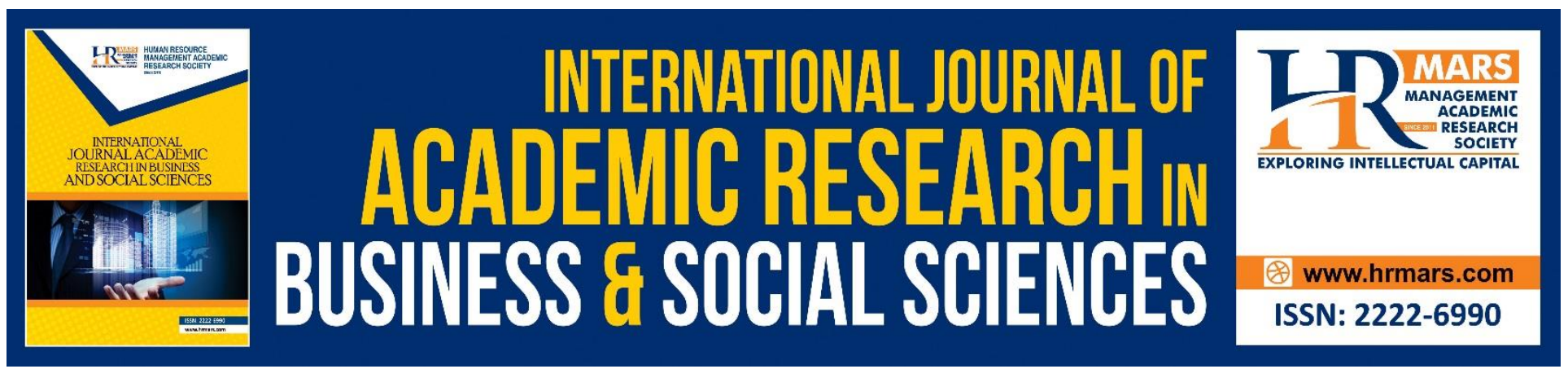

\title{
Intention to Eat Traditional Food among University Students
}

\section{Norazlina Rahmat, Mohammad Nuruddin Ramlan, Puteri Nur Athirah Ghazali, Norzaidah Ngali}

Faculty of Hotel and Tourism Management, Universiti Teknologi MARA Cawangan Terengganu, 23000 Dungun, Terengganu, Malaysia

\begin{abstract}
Traditional food represents a country, religion and the culture that brings out the unique identity of the society. Despite the importance that traditional food brings, i.e., all the essence of culture and tradition, today's generation tends to consume less traditional food as compared to the former generation. This phenomenon is contributed by several factors and it is a worrying trend: as traditional food is being consumed lesser in the coming years it will be overlooked and forgotten, and consequently the future generation may become unaware of its existence. The aim of this research is to investigate the intention to eat traditional food among students of UiTM Cawangan Terengganu, Kampus Dungun, and to determine the possible factors that influence the intention to eat traditional food among them. This study focuses on young adults aged between 19 to 26 years old from UiTM Cawangan Terengganu, Kampus Dungun. In completing this study, 346 samples were chosen randomly according to their respective faculties. The Theory of Planned Behaviour (TPB) has been adapted using three determinants, they are Attitude towards Traditional Food, Social Norms, and Perceived Behavioural Control (PBC). The results from this study indicate that the students tend to eat traditional food due to the nature of the food where it is purchase in the Dungun area. This factor will be discussed further in the Perceived Behavioural Control (PBC) variable as it has emerged as the most significant variable that leads to the intention to eat traditional food among the students. Apart from that, the theoretical and practical perspectives are also included for future research advancement in preserving the nature and importance of the traditional food for the society, especially the younger generation.
\end{abstract}

Keywords: Traditional Food, Intention to Eat, Perceived Behavioural Control, University Students.

\section{Introduction}

\section{Traditional Food}

In modernised and contemporary societies, traditional food may be a thing in the past, but the fact is that it still lingers in the minds and thoughts of most people, which is what makes it a special topic. 
Tradition defines the people and their respective cultures; correspondingly traditional food is the food that is consumed by different generations and is being passed down according to its region or locality (Norazmir et al., 2012). As it is essential to bring back memories, identities and authenticities to every culture, race, religion, and country, traditional food is also seen as a centre of one's cultural identity compared to another, which may be distinguished by the origin (Perry, 2017), belongingness and elements of the preparation of the food according to where it comes from (Norazmir et al., 2012; Kittler, Sucher \& Nelms, 2012). The preparation of the dishes is varied according to the culture. Malaysia as a multicultural country comprises several races and ethnicities and is thus rich with a wide selection of traditional foods from the Malay, Chinese, Indian, and many other ethnicities in Sabah and Sarawak (Jalis, Zahari \& Othman, 2009).

Namely, in Malaysia the food is as diverse as the ethnic compositions where the foods include the Malays, Chinese, Indian and ethnic groups from Sabah and Sarawak. According to Jabatan Warisan Negara (JWN, 2019), 213 foods has been declared as traditional foods under the Act 645 of the National Heritage Act 2005. This is the latest list of recognizable traditional foods in Malaysia, such as Pulut Durian, Kuih Ros and Capati; just as in the south of France, Ratatouille is considered as a traditional food of the region, and in another region of France- in Brittany, crepes are the traditional food there. Today, both dishes are widely consumed in the country even though they are from different areas. This shows that traditional food is diverse even in the same country. Clearly, it is important for a country to preserve its traditional foods, both for the current and future generations.

In the east coast of Malaysia, the diversity of traditional food is varied whether it is in the Northern region (Perlis, Kedah, and Perak) or the East Coast region (Kelantan and Terengganu), each region has its own identity of traditional food (Norazmir et al., 2012). This study also emphasises that Terengganu's traditional or local cuisines are heavily influenced by its neighbouring states (Pahang \& Kelantan) and country (Thailand). The only difference between Terengganu foods and Kelantan is that the former is significantly less sweet compared to the latter in most of the dishes (Norazmir et al., 2012; Jalis et al., 2009 \& Abdul Raji et al., 2017). Tourists can find some of the traditional foods in both Terengganu and Kelantan such as Akok and Nasi Kerabu. Jalis et al. (2009) have also stressed that the most important ingredient in Kelantanese cuisine is the level of sugar in a dish, as the Kelantanese prefer their foods to be sweeter in terms of taste compared to their counterpart in Terengganu. This can be seen that even though the traditional foods are similar in terms of names and appearances, the foods will have their own identity regardless of their origin.

The local traditional food of Terengganu is popular among Malaysians and the international tourist. In Terengganu particularly, there are various kinds of traditional foods such as Nasi Dagang, Satar, Ketupat Sotong and the traditional kuih among others (Tourism Terengganu, 2018).

However, these are still unknown to the local students as most of them who stay in Terengganu are from various places and backgrounds. This also verifies that most adolescents or young adults lack the knowledge and awareness of the existence of local traditional foods, and they tend to consume less compared to previous generations due to many influencing factors (Muhammad, Karim \& Hamzah, 2015; Hamzah, Ab. Karim, Othman, Hamzah \& Muhammad, 2015). 
In fact, most of the younger generations today are more exposed to the ready prepared or convenience foods such as the fast food (Muhammad et al., 2015), and this will have a negative impact towards the sustainability of the traditional food itself (Md. Sharif, Mohd Zahari, Md Nor \& Muhammad, 2015; Ting, Chuah, de Run, Phung \& Cheah, 2015). This will eventually lessen the interest of the young adults towards traditional food which they are less exposed to in the upcoming years (Hamzah et al., 2015). Notably and significantly, youths are considered as the link that bridges the preservation of the traditional food with rapid globalisation (Hamzah et al., 2015).

It is important to give the right exposure to the younger generation about the knowledge of a certain traditional food in Malaysia, especially for the longevity of the food to be kept in years to come. Apart from that, it is common today that a lot of foreign food festivals are being organised in Malaysia instead of Malaysian's own traditional food. There are some notable Malaysian traditional food fairs that have been held, such as the Selangor Food Fest (Menon, 2018) and the latest is the Kongres Makanan Warisan 2019 (Rafidi, 2019). However, it still being done in a much smaller scale and not all people are aware of these events. There would certainly be a lot of factors that will contribute to the intention of eating traditional foods by the university students and it is crucial to know these factors so that the nature of traditional food can be sustainable and its maintenance achievable. Thus, it is important for the researchers to investigate more and study on this topic of Malaysia's traditional food, especially those in Terengganu to be sustained and preserved for the future generation.

\section{Literature Review}

\section{Attitude Towards Traditional Foods}

Attitude is one of the elements that lead to the intention of studies. According to Ajzen (2005) and Sanzo, del Rio, Iglesias and Vazquez (2003), an attitude is the nature of human to react positively or negatively to an object, person, institution, or event. As a result, if the belief of a behaviour is positive, a person's attitude will be acceptable with greater chances of that person connecting with the behaviour. The attitude towards a product concept has being described in a few literatures by Rudawska, (2013) and Aikman, Min and Graham (2005), where attitude can be understood as the susceptibility to act in a way that is consistent towards the certain object. Seo, Kim and Shim (2014) have also supported this argument, that attitude is the level of acceptance of people on how they evaluate behaviour, either in positive or negative way.

Generally, traditional food is not too distinct from ethnic food. Ethnic food can be defined as food that normally originates from a heritage and culture by using the knowledge of the local ingredients from a particular ethnic group. In addition, ethnic food is culturally and socially different and sometimes, it might be welcomed by other consumers from any other ethnic groups (Yang \& Lee, 2019; Kowalczuk, Gebski \& Katarzyna, 2015). In the context of attitude, Maksan, Deronja, Kalit and Mesic (2018), have stated that ethnic food can be related with negative attitudes where not all the consumers have a positive attitude towards the ethnic or traditional foods. Therefore, due to the existing negative attitude, it has caused lower tendency to consume the ethnic or traditional food. 


\section{Social Norms}

Social norms are also one of the variables that will influence the intention to eat traditional foods. Social norms are the decision that is made by the individual either to perform an action or in this case, to eat traditional food under the influence of the people around them especially by family, friends and partners (Ajzen, 1991; Utami, 2014). Most of the time, this variable is also affected by the motivation that is gained to eat or perform an act by others (Hardin-Fanning \& Ricks, 2017). This factor may act as the behaviour of an individual and it can be seen through their psychological mechanisms, for instance, how a person acts socially in the presence of others towards a subject (Robinson, 2015).

Most of the time, both parents are the main influencers that will shape and determine the eating behaviour of their children. This can be seen through the eating behaviour of school children as the children would not have many choices to eat something that they want as it will be determined by their parents (Muhammad et al., 2015). This is an example of social norms that is happening in our daily life and the intention of eating traditional food can be said to be controlled, namely, by the parents. Thus, this study would focus more on another set of respondents- the university student who mostly lives independently without their parents influence and is thus influenced by different factors.

Moreover, Robinson (2015) also argued that the influence of social norms on others has proven that it can affect the eating behaviour and intention to eat something. If an individual is with another individual who prefers to eat traditional food, the tendency of eating the traditional food will also be higher for the person who is unfamiliar with the food. The latter person acts as an influencer towards the person who is reluctant to try the traditional food as he or she will have a right motivation to eat the food. A positive relationship between social norms and the intention to eat traditional may be achieved through this theory.

\section{Perceived Behavioural Control (PBC)}

Perceived Behavioural Control or PBC is widely used in determining the intention of an individual towards any subjects. $\mathrm{PBC}$ is the variable that makes the Theory of Planned Behaviours (TPB) differ from the Theory of Reasoned Action (TRA). The original TRA only consists of two factors which are the attitude and subjective norms. PBC is added into the TPB in 1988 by Martin Fishbein and Icek Ajzen. As have been mentioned by Ajzen (1991) in his research, PBC acts as the degree of difficulty that is encountered by an individual to perform a behaviour, but it is always reflected by their past experiences and the obstacles they have reacted to in performing the action. The research done by Richards in 2002, has clarified that the authentic traditional cuisine is always related to nostalgia, which indicates the past experiences that are encountered by an individual. Most of the time, the consumption of traditional food may be influenced by the nostalgic effect or remembrance of the food in relation to their hometown, and the degree of difficulty or motivation to acquire the product (Maichum, Parichatnon \& Peng, 2016). From this argument, it shows that there is a close relationship between the PBC and traditional food, as an individual who will consume it is when he or she has a good or unpleasant experience in consuming the food rather than trying the food for the first time or how hard it is for him or her to acquire a certain traditional food for consumption. 
In this case, the intention to eat traditional foods among local university students may vary according to the individual. Most students have a dissimilar experience towards consuming a traditional food. Some might have a pleasant history, but some might not. As aforementioned, consuming food especially traditional food will bring back nostalgia to the individual. If the person has an unpleasant experience with a particular food, he or she tends to reject the traditional food totally (Ivanova, Terziyska \& Trifonova, 2014). This can be the factor that contributes to the act or intention of eating traditional food among local university students, especially in UiTM Terengganu.

This factor also can be affected by the existence of food neophobia. People tend to reject the food that they are unfamiliar with. Food neophobia can be simply defined as the reluctance or avoidance to eat new foods (Menozzi \& Mora, 2018) and the tendency of the individual to avoid unfamiliar foods (Muhammad et al., 2016). Traditional foods might be alien to some of the young adults, where some young adults did not even recognise the name of traditional foods when they were asked (Saidi, 2018). This has raised the issue that traditional food is being forgotten and might be the reason for food neophobic to be increasing among them; they tend to be less adventurous in trying traditional foods that are unknown to them.

\section{Methodology}

Quantitative research was implemented in this study to obtain the results through a large-scale of samples using the self-administered questionnaires. The population chosen only includes the students who are in full-time mode and who stay in-campus. UiTM Cawangan Terengganu, Kampus Dungun, has been chosen as the target population because the students are mostly from diverse backgrounds, from across Malaysia and this will generalise the results instead of only representing Terengganu only.

Stratified sampling method had been chosen to divide the overall population of Cawangan Terengganu Kampus Dungun students and as the sampling technique. Students were chosen from their respective faculties and were divided equally by the total sample needed. The sample size was selected from the total population of the students of UiTM Cawangan Terengganu, Kampus Dungun. Based on the current enrolment report by Hal Ehwal Akademik (HEA), it was indicated that the total population of UiTM Cawangan Terengganu, Kampus Dungun, students was 3,545. Therefore, the sample size was chosen according to Krejcie and Morgan table (1970). By referring to the table, it was deduced that the researchers used the total population of $\mathrm{N}=3545$, then the sample size for this study would be $n=346$. 
INTERNATIONAL JOURNAL OF ACADEMIC RESEARCH IN BUSINESS AND SOCIAL SCIENCES

Vol. 11, No. 13, Beyond 2021 and COVID-19 - New Perspective in the Hospitality \& Tourism Industry. 2021, E-ISSN: 2222-6990 @ 2021 HRMARS

Table 1: Distribution of Respondents

\begin{tabular}{lll}
\hline Faculty & No. of students & No. of students chosen as sample \\
\hline Faculty of Hotel \& Tourism Management & 1485 & $1485 / 3545 \times 346=145$ \\
\hline Faculty of Business Management & 1415 & $1415 / 3545 \times 346=138$ \\
\hline Faculty of Accountancy & 321 & $321 / 3545 \times 346=31$ \\
\hline Faculty of Electrical Engineering & 244 & $244 / 3545 \times 346=24$ \\
\hline Academy of Contemporary Islamic Studies & 80 & $80 / 3545 \times 346=8$ \\
\hline Total & $\mathbf{3 5 4 5}$ & $\mathbf{3 4 6}$ \\
\hline
\end{tabular}

\section{Result and Analysis}

\section{Demographic Profiles}

With regards to gender distribution, the majority $(74.9 \%, \mathrm{~N}=259)$ was female and the rest $(25.1 \%$, $\mathrm{N}=87$ ) is male. Most of the respondents were in the age range of 18 to 20 years old which accounted for $48.6 \%$ of the total respondents $(\mathrm{N}=138)$. Based on the respondents' faculty, those who were from the Faculty of Hotel \& Tourism Management dominated the total number of respondents with $41.9 \%$ $(\mathrm{N}=145)$. Students of Cawangan Terengganu, Kampus Dungun consisted of three levels which were the pre-diploma, diploma, and bachelor's degree. However, there were only respondents gathered from both diploma and bachelor's degree. From the figure, 54.9\% ( $N=190)$ were diploma students and $45.1 \%(\mathrm{~N}=156)$ were bachelor's degree students.

\section{Intention to Eat Traditional Food based on Attitude}

Table 2 shows that most of the respondents agreed that traditional food has a tasty, visual appeal, texture, and delightful aroma, with a mean score of $(M=4.22, S D=0.708)$. The traditional food is perceived as tasty due to the main characteristics of the traditional food itself which are rich in herbs and spices: the main ingredients in most of the traditional food that uses coconut milk gives a rich, thick and creamy texture as well as a spicy taste, as using the herbs and spices have enhanced the taste and aroma of the traditional food (Abdul Raji, Ab Karim, Che Ishak and Arshad, 2017). In addition, most of the respondents have also agreed that traditional food has its own authentic recipe and preparation process. Md. Norazmir et al. (2012) and Sharif et al. (2016) have also supported this statement, that traditional food has been passed down from one generation to another generation including all those cooking techniques and processes, thus, maintaining the authenticity of the food being preserved even though the food is cooked by a different person. 
INTERNATIONAL JOURNAL OF ACADEMIC RESEARCH IN BUSINESS AND SOCIAL SCIENCES

Vol. 11, No. 13, Beyond 2021 and COVID-19 - New Perspective in the Hospitality \& Tourism Industry. 2021, E-ISSN: $2222-6990$ @ 2021 HRMARS

Table 2: Attitudes towards Intention to Eat Traditional Food

\begin{tabular}{llc}
\hline \multicolumn{2}{c}{ Descriptive Statistics } & Mean \\
\hline Item & 4.22 & Std. Deviation \\
\hline 1. Tasty, visual appeal, texture, and delightful aroma & 3.75 & 0.708 \\
\hline 2. More nutritional for a balanced diet & 4.13 & 0.824 \\
\hline 3. Satisfy my appetite and makes me feel good & 4.08 & 0.737 \\
\hline 4. Happy to try traditional food & 0.668 \\
\hline
\end{tabular}

\begin{tabular}{lll}
\hline 5. Enjoy consuming anywhere and anytime & $\mathbf{4 . 0 4}$ & $\mathbf{0 . 7 5 8}$ \\
\hline 6. Sufficient knowledge about names & 3.68 & 0.825 \\
\hline 7. Authentic recipe and preparation process & 4.21 & 0.681 \\
\hline 8. History of their existence & 4.20 & 0.710 \\
\hline 9. Special occasion & 4.15 & 0.708 \\
\hline 10. Traditional food connected to my past & 3.68 & 0.821 \\
\hline 11. Forbid eating some traditional food from other races & 3.73 & 0.773
\end{tabular}

Intention to Eat Traditional Food based on Social Norm

Table 3 showed that most of the respondents agreed that their parents showed how much they enjoyed traditional food, this mean score $(M=4.00, S D=0.754)$ was followed by "My parents allow me to be involved in preparing traditional food", with the mean score (M=3.95, SD=0.773). Abdul Raji et al. (2017), have mentioned in their study that a mother plays a vital role in the children- to preserve the cultural tradition, especially in preparing traditional food. This is the proof that parents enjoy eating the food as well as teaching their children on how to prepare the traditional food especially during special occasions and festive seasons like Eid, Haj, Deepavali, Chinese New Year etc. Usually, during family gatherings, families will cook traditional food and eat together. Parents are more cheerful when preparing traditional food together with their children. 
INTERNATIONAL JOURNAL OF ACADEMIC RESEARCH IN BUSINESS AND SOCIAL SCIENCES

Vol. 11, No. 13, Beyond 2021 and COVID-19 - New Perspective in the Hospitality \& Tourism Industry. 2021, E-ISSN: 2222-6990 @ 2021 HRMARS

Table 3: Social Norm towards Intention to Eat Traditional Food

\begin{tabular}{lcc}
\hline \multicolumn{1}{c}{ Descriptive Statistics } & & Mean \\
\hline Item & $\begin{array}{c}\text { Std. } \\
\text { Deviation }\end{array}$ \\
\hline 1. My friends and I regularly eat traditional food & 3.58 & 0.838 \\
\hline 2. My friends tell me I should buy traditional food & 3.42 & 0.810 \\
\hline 3. My friends and I enjoy chatting about traditional food & 3.61 & 0.817 \\
\hline 4. My friends and I order traditional food & 3.46 & 0.817 \\
\hline 5. My parents encourage me to eat traditional food & 3.86 & 0.780 \\
\hline 6. My parents encourage me to try other types of traditional food & 3.80 & 0.741 \\
\hline 7. My parents and I order traditional food & 3.57 & 0.797 \\
\hline 8. My parents allow me to be involved in preparing traditional food & 3.95 & 0.773 \\
\hline 9. My parents show how much they enjoy traditional food & 4.00 & 0.754 \\
\hline 10. My parents usually eat traditional food when they are eating together & 3.84 & 0.805 \\
\hline 11. My parents prepare a variety of traditional food & 3.80 & 0.808 \\
\hline
\end{tabular}

\section{Intention to Eat Traditional Food based on Social Norm}

For Perceived Behavioural Control (PBC), table 4 shows that most of the respondents agreed that tasting more ethnic food provides a form of knowledge and thus they prefer to eat traditional food that they are used to; the results indicate the mean score $(M=4.08, S D=0.728)$ and $(M=4.08, S D=$ 0.728 ) respectively. Understandably, people tend to develop a certain knowledge on a food that they have consumed especially on the ingredients, preparation and the origin of the food (Cayot, 2007) and it is more than about the taste. People are more likely to eat traditional foods that they are familiar with. Bell, Adhikari Chambers, and Suwonsichon (2011) have mentioned that a traditional food product could be determined by its taste, by the sensory attributes of the person who has consumed the traditional food.

Table 4: Perceived Behavioural Control (PBC) towards Intention to Eat Traditional Food Descriptive Statistics

\begin{tabular}{llc}
\hline Item & Mean & Std. Deviation \\
\hline 1. Easy to purchase & 3.95 & 0.813 \\
\hline 2. Cheap & 3.90 & 0.792 \\
\hline 3. Buying after class & 3.83 & 0.812 \\
\hline 4. Given the opportunity to try & 4.06 & 0.719 \\
\hline 5. Tasting more ethnic food provides some knowledge & 4.08 & 0.718 \\
\hline 6. Prefer to eat traditional food that I am used to & 4.08 & 0.728 \\
\hline 7. Easy to prepare and suitable to eat anytime & 3.86 & 0.766 \\
\hline 8. Lunch away from home, traditional food is my first choice & 3.63 & 0.843 \\
\hline 9. Snack between meals & 3.81 & 0.788 \\
\hline 10. Sources of ingredients forbid me to eat & 3.64 & 0.823 \\
\hline 11. Seasonal based product & 3.83 & 0.726 \\
\hline 12. Easily available & 3.99 & 0.689
\end{tabular}




\section{Conclusion}

This study has enabled the conclusion that traditional food is important in giving meaning and identity in people's life and it is crucial to keep it that way It was found that there was no significant difference in terms of the results between the previous studies (Muhammad et al., 2015) as compared to this study where the PBC appeared to be the highest determinant in determining the intention to eat traditional food among students of UiTM Cawangan Terengganu Kampus Dungun. This is due to the way of life, for school children are shaped by their parents and are mostly influenced by family and friends as compared to university students, who live independently (Kimura et al., 2010) and no longer conform to their parents and family way of life (Savage et al., 2007).

\section{Corresponding Author}

Norazlina Rahmat. Faculty of Hotel and Tourism Management, UiTM Cawangan Terengganu Kampus Dungun, 23000, Dungun, Terengganu

Email: noraz335@uitm.edu.my

\section{References}

Abdul Raji, M. N., Ab Karim, S., Che Ishak, F. A., \& Arshad, M. M. (2017). Past and present practices of the Malay food heritage and culture in Malaysia. Journal of Ethnic Foods, 4(4), 221-231.

Aikman, S. N., Min, K. E., \& Graham, D. (2005). Food attitudes, eating behavior, and the information underlying food. Attitudes, 47(1), 111-4.

Ajzen, I. (1991). The theory of planned behavior. Organizational Behavior and Human Decision Processes, 50(2), 179-211.

Ajzen, I. (2005). Attitudes, Personality and Behaviour (Second Edition). Open University Press.

Bell, B., Adhikari, K., Chambers, E., \& Suwonsichon, T. (2011). Ethnic Food Awareness and Perceptions of Consumers in Thailand and the United States. Nutrition \& Food Science, 41(4), 268-277. https://doi.org/10.1108/00346651111151401

Cayot, N. (2007). Sensory quality of traditional foods. Food chemistry, 101(1), 154-162.

Hamzah, H., Ab. Karim, M. S., Othman, M., Hamzah, A., \& Muhammad, H. (2015). Challenges in Sustaining the Malay Traditional Kuih among Youth. International Journal of Social Science and Humanity, 5(5).

Hardin-Fanning, \& Ricks, J. M. (2017). Attitudes, Social Norms and Perceived Behavioral control factors influencing participation in a cooking skills program in rural central Appalachia. Glob Health Promot. 2017 Dec; 24(4), 43-52. https://doi.org/10.1177/1757975916636792

Ivanova, L., Terziyska, I., \& Trifanova, J. (2014). Characteristics of Traditional Food-the viewpoint of the tourism business. Service Management, 14. 123-130.

Jabatan Warisan Negara. (2019). Makanan warisan. Retrieved from http://www.heritage.gov.my/index.php/makanan-warisan

Jalis, M. H., Zahari, M. S., Zulkifly, M. I., \& Othman, Z. (2009). Gastronomic products as tourist motivational factors: An opportunity to Malaysia. Tourism Educators of Malaysia Conference, 57-70.

Kowalczuk, I., Gebski, J., \& Milewska, K. (2015). Consumers' Attitudes Towards Novel Foods as Illustrated by The Example of Ethnic Food. Journal of Agribusiness and Rural Development, 16, 795-803. https://doi.org/10.17306/J.JARD.2017.00343 
Kittler, P. G., Sucher, K. P., \& Nelms, M. N. (2012). Food and Culture (6th ed.). Belmont, CA: Wadsworth

Krejcie, R. V., \& Morgan, D. W. (1970). Determining sample size for research activities. Educational and psychological measurement, 30(3), 607-610.

Maksan, M. T., Deronja, Z., Kalit, M. T., \& Mesic, Z. (2018). Consumers' attitudes towards ethnic food consumption. Journal of Central European Agriculture, 19(2), 349-367.

Menon, P. (2018). Going Traditional at Selangor Food Fest. The Star Online. Retrieved on 16 June 2019. https://www.thestar.com.my/metro/metro-news/2018/12/27/going-traditional-atselangor-food-fest/

Menozzi, D., \& Mora, C. (2018). The Food Neophobia Scale and Young Adults' intention to Eat Insect Products. International IJC, 46, 68-76. https://doi.org/10.1111/ijcs.12485.

Muhammad, N. H., Ab. Karim, M. S., \& Hamzah, H. (2015). Intention to eat traditional food among boys and girls in Malaysia. International Journal of Social Science and Humanity, 5, 450-453. https://doi.org/10.7763/IJSSH.2015.V5.498

Perry, M. S. (2017). Feasting on Culture and Identity: Food Functions in a multicultural an transcultural Malaysia. 3L The Southeast Asian Journal of English Language Studies, 23(4), 184-199. https://doi.org/10.17576/31 2017-2304-14

Rafidi, R. (2019Keeping food heritage alive. New Straits Times. Retrieved from http://www.nst.com.my.

Richards, G. (2002). Traditional and contemporary culture and tourism. In Belda, E. and Laaksonen, A. (eds) Pyrenne: a European project to Foster linguistic diversity and the role of tradition in contemporary arts production. Fundacio Interarts, Barcelona, 65-73.

Robinson, E. (2015). Perceived Social Norms and Eating Behaviour: An Evaluation of Studies and Future Directions. Physiology \& Behavior, 152 (part B), 397e401.

Rudawska, E. D. (2013). Customer loyalty towards traditional products - polish market Experience. British Food Journal, 16(11), 1710-1725. https://doi.org/10.1108/BFJ-10-2013-0299

Saidi, N. (2018). Kuih Melayu semakin pupus. Retrieved April 16, 2019, from http://www.utusan.com.my/mega/kuih-melayu-semakin pupus-1.752093

Sanzo, M. J., Del Rio, A. B., Iglesias, V., \& Vázquez, R. (2003). Attitude and satisfaction in a traditional food product. British Food Journal, 105(11), 771-790.

Savage, J. S., Fisher, J. O., \& Birch, L. L. (2007), Parental Influence on Eating Behavior: Conception to Adolescence. The Journal of Law, Medicine \& Ethics, 35, 22-34. https://doi.org/10.1111/j.1748 720X.2007.00111.x

Seo, S., Kim, O. Y., \& Shim, S. (2014). Using the theory of planned behavior to determine factors influencing processed foods consumption behavior. Nutrition research and practice, 8(3), 327335.

Sharif, M. S. M., Zahari, M. S. M., Nor, N. M., \& Muhammad, R. (2016). The importance of knowledge transmission and its relation towards the malay traditional food practice continuity. ProcediaSocial and Behavioral Sciences, 222, 567-577.

Ting, H., Chuah, F., de Run, E. C., Phung, M., \& Cheah, J. H. (2015). Ethnic Food Consumption Intention: A Groundwork Study on Consuming Dayak Food using Theory of Planned Behaviour. Conference proceedings from the 11th Asian Academy of Management International Conference, October 2-4, Park Royal Hotel, Penang. 
INTERNATIONAL JOURNAL OF ACADEMIC RESEARCH IN BUSINESS AND SOCIAL SCIENCES

Vol. 11, No. 13, Beyond 2021 and COVID-19 - New Perspective in the Hospitality \& Tourism Industry. 2021, E-ISSN: 2222-6990 @ 2021 HRMARS

Tourism Terengganu. (2018). Terengganu Guide - Culture, Art, and Heritage Booklet 2018. Retrieved from Tourism Terengganu website: http://tourism.terengganu.gov.my/attachments/article/56 8/Terengganu\%20Guide\%20-\%20Culture,\%20Arts\%and\%20Heritage\%20Booklet.pdf.

Utami, H. D. (2004). Consumer behaviour and food processor response towards ethnic food in East Java, Indonesia. Unpublished doctoral thesis, Massey University, Palmerston North, New Zealand.

Yang, J., \& Lee, J. (2019). Application of Sensory Descriptive Analysis and Consumer Studies to Investigate Traditional and Authentic Foods: A Review. Foods, 8(2), 54. https://doi.org/10.3390/foods80200. 